\title{
The Bioavailability of Manganese in the Marigold (Calendula officinalis L.) Grown on Alkaline Soil
}

\section{Zorica Hodžić, Mirzeta Saletović, Aida Crnkić, Aldina Kesić, Nadira Ibrišimović Mehmedinović, Almir Šestan}

Department of General and Inorganic Chemistry, Faculty of Natural Science and Mathematics, University of Tuzla, Tuzla, Bosnia and Herzegovina

\section{Email address:}

zorica.hodzic@untz.ba (Z.Hodžić),mirzeta.saletovic@untz.ba (M. Saletović), aldina.kesic@untz.ba (A. Kesić), aida.crnkic@untz.ba (A.Crnkić), nadira.ibrisimovic@untz.ba (N. I. Mehmedinović), almir.sestan@untz.ba (A. Šestan)

\section{To cite this article:}

Zorica Hodžić, Mirzeta Saletović, Aida Crnkić, Aldina Kesić, Nadira Ibrišimović Mehmedinović, Almir Šestan. The Bioavailability of Manganese in the Marigold (Calendula officinalis L.) Grown on Alkaline Soil. American Journal of Applied Chemistry.

Vol. 4, No. 4, 2016, pp. 141-145. doi: 10.11648/j.ajac.20160404.14

Received: June 6, 2016; Accepted: June 16, 2016; Published: July 15, 2016

\begin{abstract}
The research includes analysis of: $\mathrm{pH}$ value, organic matter content, and the total concentration of manganese in eleven soil samples from different localities northeast of Bosnia and Herzegovina. Sequential extractions of soil samples were also performed to determine the content of some form of binding manganese. Concentration of manganese in the flowers of calendula were also found and tested at these sites. From the obtained measurement, BCF (Bioconcentration Factor) values were calculated for the tested metal. Soil $\mathrm{pH}$ had values from 7.84 to 8.54 , which puts them in the category of alkaline and strongly alkaline soil. The total concentration of manganese measured in soil samples do not exceed the limit values or are above average values. In the analyzed soil samples, the minimum content of manganese in the exchangeable fraction and the largest in the residual fraction and bound for oxides of manganese and iron. The concentrations of manganese in the flowers of calendula have not exceeded the permitted value. Statistical analysis of the results showed a weak linear correlation between $\mathrm{pH}$ value of an aqueous solution of the soil and the content of manganese in the flower, and linear correlation between manganese in the exchangeable fraction and the content of manganese in the flower. The calculated BCF values are very low and suggest that calendula growing on alkaline soil hasn't got an expressed potential for accumulation of manganese.
\end{abstract}

Keywords: Manganese, Soil, Sequential Extraction, Marigold, Bioavailability

\section{Introduction}

Adoption of metals from soil by plants is complex and depends on the concentration, mobility, chemical properties and dissolved forms of metals; biochemical condition and texture of the soil; meteorological conditions, i.e. temperature, humidity, durability emissions, as well as plant species. Bioavailability is considered to be a fraction of a metal in the soil that is truly accessible to the receptor organism, which means that metal must be agile enough to come into contact with the plant and to the appropriate chemical form that allows it to be adopted by a plant and after the adoption to be switched in the metabolism [1]. Metal fractions that have low metal bonds to the respective fraction of soil are believed to be directly available to the plants which include: a metal dissolved in water (are in the form of ions in the soil solution), exchangeable fraction (metals adsorbed on soil colloids) and readily dissolved organometallic complexes. The most important physiological factors of bioavailability are: adsorption of the cell wall (type and quantity), the excretion of organic compounds, proteins and gas substances [2].

Manganese content for most types of soil is from 500 to $1000 \mathrm{mg} / \mathrm{kg}$ [3]. Average concentration of manganese in the some soil samples of northern Europe is $400 \mathrm{mg} / \mathrm{kg}$, in Sweden $550 \mathrm{mg} / \mathrm{kg}$; Seville $470 \mathrm{mg} / \mathrm{kg}$ [4]. There are three oxidation states of manganese in the soil: $\mathrm{Mn}^{2+}, \mathrm{Mn}^{3+}, \mathrm{Mn}^{4+}$. The content of exchangeable manganese in aqueous soil is $\mathrm{Mn}^{2+}$ and is only available to plants. A mechanism of adopting manganese in the plant is carried out similarly to the other monovalent and divalent ions. The first phase is adsorbed on the surface of roots, and then actively transferred to the interior 
of the cell [5]. The mobility of $\mathrm{Mn}^{2+}$ in plants is relatively small, but still better than the mobility of copper and iron. Based on his role in the transport of substances, it represents one of the major metals in the life of plants. And also participates in the activation of enzymes (enolase, carboxylase, MnSOD), in activation of the process of phosphorylation, carbohydrate metabolism, transmission and consumption of energy and photosynthesis. Most manganese accumulates in the leaf [6]. The plant tolerance to excess manganese depends on the plant species or genotype, a manganese excess as a result has oxidative stress of plant cells [7].

Marigold (Calendula officinalis L.) from the family Asteraceae, aster, is a hardy plant. It originates from southern Europe and the Mediterranean; gives a flower with orange or yellow color [8]. Marigold is present in the meadows, pastures and along the roads of the lower mountains. It contains some medical substances: essential oils, glycosides, carotenoids, bitter substances, mucus, ferments and organic acids. Marigold seed is harvested during June, July and August, collected and dried in a draft in a thin layer. Flowers are commonly used as a source of essential oils as a natural pigment. Calendula is used for: wound healing, prevents infection and promotes granulation. It can be locally applied to inflammatory changes in the lining of the mouth and throat wound. Cromack lists four different possibilities of using calendula: as medicinal plants, in the cosmetic industry and in the production of natural colors [9]. Russians used it for the manufacture of compositions that are used in the symptomatic treatment of some forms of cancer, and its antiHIV properties are recently revealed [10].

\section{Materials and Methods}

The study includes the analysis: $\mathrm{pH}$ value, organic matter content, and the total concentration of manganese in eleven soil samples from different localities northeast of Bosnia and Herzegovina. After sampling, the soil was spread in a thin layer on a clean surface, and the visible parts of the plant material were manually removed. The soil was left to dry, and then homogenized (to granule size $<2 \mathrm{~mm}$ ). Sequential extractions of soil samples were also performed to determine the content: the removable and solute fractions (fraction I) of the manganese bounded to carbonates (fraction II), manganese bounded to iron and manganese oxides (fraction III), manganese bounded to the organic substance (fraction IV) and the residual manganese (fraction V)[11]. Determination of the $\mathrm{pH}$-value is performed in the suspension of soil with water (active acidity), with the potentiometric pH-meter WTW Ino lab 730. The content of organic matter was determined in the soil by the standard method of annealing the samples in an oven at a temperature of $500-600^{\circ} \mathrm{C}$. Concentrations of manganese in the flowers of calendula are tested at these sites. Marigold sample preparation for the analysis was carried out using platinum crucible with a sample mass of $0.5 \mathrm{~g}$ and then burnt on the burner. The overall manganese content in soil samples and calendula flowers is determined by AAS method "Perkin
Elmer" ANALYST 200 spectrophotometer. From the obtained measurement BCF values were calculated (Bioconcentration Factor) for the tested metal. Bioconcentration factor (BCF) is calculated as the ratio of the concentration of metals in the plant (the part to use-flower) in relation to the ground in which the plant is grown [12].

\section{Results and Discussions}

\subsection{Results and Discussion of Soil Analysis}

The $\mathrm{pH}$ of the soil is of a great importance for the growth and development of plants. Some plant species can normally be developed only in certain $\mathrm{pH}$ intervals. The $\mathrm{pH}$ value of the soil largely depends on the amount of ions accessible to plants. If the soil is more acidic solubility of the metal typically increases. The complex influence of $\mathrm{pH}$ value of the soil is determined with soil microbial activity as the $\mathrm{pH}$ value has a direct impact on the micro flora soil i.e. on the content of bacteria and fungi in the soil. The desirable $\mathrm{pH}$ value of arable soil layer is 6.5 or more, because it provides a good immobilization of heavy metals and their minimal bioavailability as well as optimal availability of essential micro and macro elements. The increase of $\mathrm{pH}$ values, over 8 , the availability of manganese is significantly reduced and symptoms of lack of this element appear [13]. Results of measuring the $\mathrm{pH}$ value of the soil in aqueous solution are shown in Table 1. The values are 7.84 to 8.54 , which classifies the tested soil to alkaline category (7.7 to 7.9 ) and highly alkaline soils $(>8.0)$. The content of organic matter in the soil is of a special interest in the research of metal sorption in soil due to the tendency of transition of metal cations to form stable complexes with organic ligands [14]. Organic matter influences the mobility of metals depending on the characteristics of organic matter, and the relation between the soluble organic acid which acts as carrier of metal components and high molecular weight which retain metals [15]. The content of organic substances in the samples shown in Table 1 rated from $6.53 \%$ to $8.73 \%$, which classified the soil into the category with a high content of organic matter (5\%-10\%). The total measured concentration of manganese (Table 1) in the samples does not exceed the limits of this metal in the soil (80$1300 \mathrm{mg} / \mathrm{kg})$, but are above the average $(530 \mathrm{mg} / \mathrm{kg})$ [16].

Table 1. The content of organic matter, total manganese $p H$ value in soil samples.

\begin{tabular}{llll}
\hline $\begin{array}{l}\text { Number of the } \\
\text { soil sample }\end{array}$ & $\begin{array}{l}\text { The content of } \\
\text { organic matter }(\%)\end{array}$ & $\begin{array}{l}\text { pH-value of the } \\
\text { soil }\end{array}$ & $\begin{array}{l}\text { Total content of } \\
\text { Mn (mg/kg) }\end{array}$ \\
\hline 1. & 7.55 & 7.84 & 685 \\
2. & 7.04 & 8.17 & 725 \\
3. & 6.71 & 8.10 & 730 \\
4. & 6.72 & 8.17 & 690 \\
5. & 8.73 & 7.89 & 735 \\
6. & 8.23 & 7.90 & 805 \\
7. & 8.06 & 8.51 & 660 \\
8. & 6.96 & 8.53 & 685 \\
9. & 6.53 & 8.38 & 790 \\
10. & 6.77 & 8.54 & 905 \\
11. & 6.84 & 8.32 & 810 \\
\hline
\end{tabular}


However, access, adoption and phytotoxicity of heavy metals are determined not only by the total content in the soil, but also by the chemical form, affinity of plants, and individual or interactive effect of different soil characteristics. Sequential extraction results are shown in Table 2. In tested samples of soil, the lowest manganese content is in the removable phase (fraction I) from $0.05 \%$ to $0.72 \%$. Relatively low manganese content is related to organic matter (2\%-5.19\%; Fraction IV) and manganese bounded to carbonates $(6.17 \%-19.3 \%$; Fraction II). The highest percentage of manganese is found in the residual fraction $(15 \%-51.82 \%$; Fraction $\mathrm{V})$ and tied for oxides of manganese and iron (29.80\%-74\%; Fraction III).
High levels of total manganese are usually attributed to the presence of the concentration of manganese oxides. Manganese oxides are important component of elements of the fourth stage of the soil. The results show a low value of available manganese (fractions I and II) in the soil samples, and a high strength of its binding to the solid phase of soil. The research results are consistent with the results of Milivojević's paper where the arable land share carbonate phase amounts to $13.7 \%$ of the total manganese content, while on the meadow vertisols the amount is $15.45 \%$. Milivojević also states that the ecotoxicity of manganese can be manifested only in cases of low $\mathrm{pH}$ value of the soil and ground water saturation phenomena [17].

Table 2. The content of manganese in the soil fractions.

\begin{tabular}{llllll}
\hline Number of the soil sample & $\begin{array}{l}\text { Mn }(\mathbf{m g} / \mathbf{k g}) \\
\text { Fraction I }\end{array}$ & $\begin{array}{l}\text { Mn }(\mathbf{m g} / \mathbf{k g}) \\
\text { Fraction II }\end{array}$ & $\begin{array}{l}\text { Mn (mg/kg) } \\
\text { Fraction III }\end{array}$ & $\begin{array}{l}\text { Mn }(\mathbf{m g} / \mathbf{k g}) \\
\text { Fraction IV }\end{array}$ & $\begin{array}{l}\text { Mn (mg/kg) } \\
\text { Fraction V }\end{array}$ \\
\hline 1. & 1.7 & 78.4 & 261.2 & 22.8 & 320.9 \\
2. & 1.7 & 111.6 & 295.2 & 26.5 & 290.0 \\
3. & 1.0 & 124.8 & 283.2 & 37.9 & 283.1 \\
4. & 0.8 & 117.3 & 253.8 & 30.0 & 288.1 \\
5. & 1.4 & 140.4 & 237.8 & 32.6 & 318.8 \\
6. & 2.0 & 129.8 & 239.9 & 26.1 & 407.2 \\
7. & 1.75 & 50.73 & 429.4 & 18.3 & 160.25 \\
8. & 3.25 & 45.0 & 507.3 & 23.4 & 106.05 \\
9. & 3.0 & 48.8 & 511.1 & 21.6 & 205.5 \\
10. & 3.0 & 45.0 & 535.8 & 22.0 & 299.2 \\
11. & 2.38 & 50.5 & 547.2 & 18.0 & 191.92 \\
\hline
\end{tabular}

\subsection{Results and Discussion of Flower Analysis}

According to the World Health Organization, nearly $80 \%$ of people in the less civilized communities use medicinal plants only for treating various diseases [18]. The plants present on the soil with a high content of heavy metals created a physiological mechanism qualified to handle higher concentrations of heavy metals. This mechanism is based on slower, or with less adoption, or on a particular system of internal detoxification. However, when the concentration of metals in the soil exceeds a certain critical value, the mechanism of regulation of the adoption is being damaged causing the adoption and accumulation of heavy metals in plants suddenly become uncontrolled and very intense. Knowing the content of heavy metals in products of plant origin is of an essential importance in terms of nutritional and physiological value, food safety and applied process of production or processing. Modern production systems increase the risk of accumulation of heavy metals in plants for which imposes a continuing need for monitoring the concentration of heavy metals in plants and plant products. Human organism requires using the micro and macro elements in specified amounts which are necessary for growth and good health. This observation is confirmed by studies that suggest the risk of consuming medicinal plants with increasing concentrations of heavy metals on human health. It was confirmed that long-term consumption of medicinal plants cause health problems due to the potential presence of heavy metals [19]. Toxic concentrations of manganese are present in acidic soil, and with the increase of the $\mathrm{pH}$ value $(>7.5)$ its availability to the plant is reduced. The natural content of manganese in plants is in the range of 20-240 mg / kg of dry matter. However, more important than the total concentration of manganese in the soil are easily available manganese concentrations and they are much lower than the average values $(20-50 \mathrm{mg} / \mathrm{kg})$ [20].

Table 3 shows the analysis results of the total concentration of manganese in the flower plants Calendula officinalis due to the use and importance of marigold in phytopharmacy.

Table 3. The content of manganese in calendula flower and BCF value.

\begin{tabular}{lll}
\hline Number of the flower sample & Mn in the flower $(\mathbf{m g} / \mathbf{k g})$ & BCF \\
\hline 1. & 12 & 0.0175 \\
2. & 13 & 0.017 \\
3. & 13 & 0.017 \\
4. & 14 & 0.02 \\
5. & 12 & 0.016 \\
6. & 16 & 0.019 \\
7. & 16 & 0.037 \\
8. & 19 & 0.027 \\
9. & 15 & 0.0189 \\
10. & 18 & 0.0198 \\
11. & 17 & 0.02 \\
\hline
\end{tabular}

To meet the metabolic functions in plant cells, the content of manganese is required at low concentrations $(20 \mathrm{mg} / \mathrm{kg})$ [21]. Analyzing the results obtained, the concentration of manganese in the flowers of calendula assume that there is a lack of negative (depressed) impact of increased concentration of manganese in the soil at the plant due to its reduced accessibility, but also literature data that suggest that 
the manganese is a component of chlorophyll, and according to its physiological role, it mostly accumulates in leaves [22]. Comparing the value of total manganese in the soil and calendula flower, it is not established a linear relationship which is in line with other studies [23]. The basic physiological characteristic of plants is to defend the system against the harmful effects of heavy metals. Bioconcentration factor value $(\mathrm{BCF})>1$, is used to assess the potential plant species for phytoextraction and phytostabilization. Bioconcentration factor values are: 1-10-high, low values of 0.1-1 and very low 0.01-0.1 [24]. BCF values obtained from conducted research are very low and range from 0.016 to 0.037 (Table 3).

With the statistical analysis of the results, weak linear correlation between $\mathrm{pH}$ value of an aqueous solution of the soil and the content of manganese in the flower was determined (correlation coefficient $\mathrm{R}^{2}=0.595 ; \mathrm{p}<0.05$ ) and linear correlation between fractions I (interchangeable fraction) and manganese content in the flower (coefficient correlation $\mathrm{R}^{2}=0.5755 ; \mathrm{p}<0.05$ ). (Figure 1. and Figure 2.). Because of these, we can easily explain presence of relatively low content of manganese in the flower of the total metals in the soil. Low concentrations of manganese in the exchangeable fraction and a high $\mathrm{pH}$ value of the soil are likely to be limiting factors for the adoption and translocation of manganese in marigold flowers.

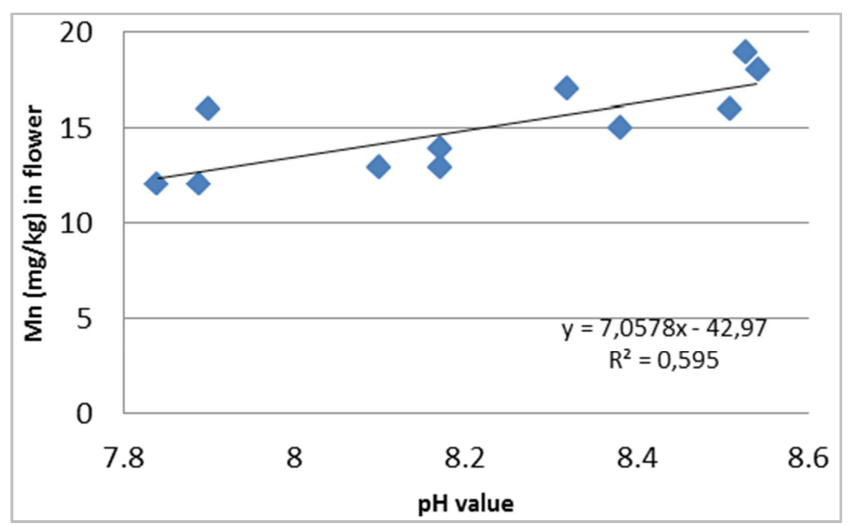

Figure 1. Linear correlation between pH-value of soil and content $\mathrm{Mn}$ in flower.

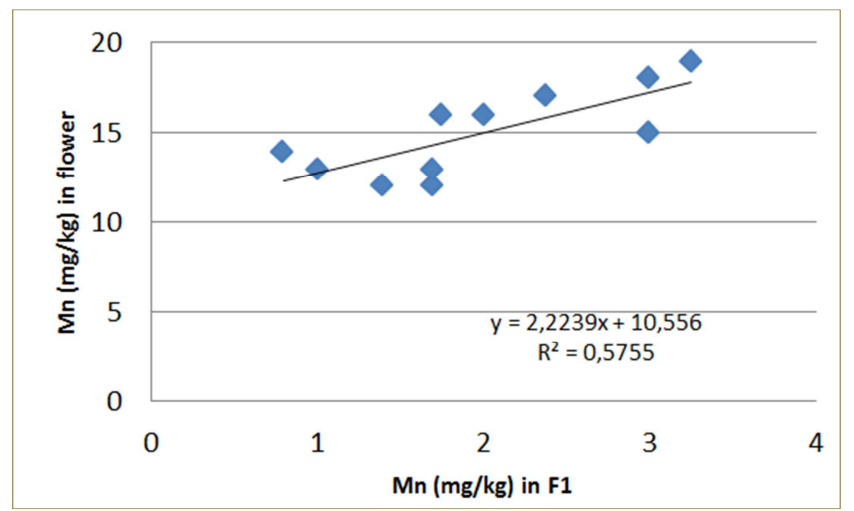

Figure 2. Linear correlation between Mn content in fraction F1 and $\mathrm{Mn}$ content in the flower.

\section{Conclusion}

Total manganese concentration measured in soil samples do not exceed the limits of this metal, but are above the average of European soil. The highest percentage of manganese is found in moieties of poorly available plants (Fraction II and Fraction V). Although the relatively high content of manganese is bounded with manganese and iron oxides, there obviously come to immobilization of metals due to the high $\mathrm{pH}$ of the soil. Low concentrations of manganese in the exchangeable fraction and a high $\mathrm{pH}$ value of the soil are likely to be limiting factors for poor adoption and translocation of manganese in marigold flowers. The calculated $\mathrm{BCF}$ values are very low and suggest that calendula growing on alkaline soil has expressed the potential for accumulation of manganese.

\section{Acknowledgment}

Authors thank to the Federal Ministry of Education and Science of Bosnia and Herzegovina - FMON for financial support of this research (as a part of the Project: "Distribution of heavy metals $(\mathrm{Cu}, \mathrm{Zn}, \mathrm{Mn})$ in soil-plant system“)

\section{References}

[1] Parker D. R., Pedler J. F. Recvaluating the free-ion activity model of trace metal availability to higher plants. Plant and soil. 1997, 196: 223-228.

[2] Brummer G. W. Heavy metal Species, Mobility and Availability in Soils. In: Bernhold, M, Brinkman, F. E., Sadler P. J. The Importance of chemical Speciation in Enviromental Processes. Dahlen Konferenzien, Berlin, Heidelberg, New York, 1986.

[3] Adriano D. C. Trace Elements in the Terrestrial Environment, Springer, New York, 1986. 263-277.

[4] Madrid L., Diaz-Barrientos E., Madrid F. Distribution of haevy metal concentrations of urban soils in parkers of Seville. Chemosphere. 2002, 49: 1301-1308.

[5] More D. P. Mechanism of micronutrient uptake by plants. In: Micronutrients in Agriculture. Soil Sci Soc Amer. 1972: 171-198.

[6] Marschener H. Mineral Nutrition of Higher Plants. Academic Press, San Diego, CA. 1995: 889.

[7] Horst W. J. The physiology of manganese toxicity. In: Manganese in Soil and Plants, Kluwer Academic Publishers, Dordrecht, The Nedtherlands. 1988: 175-178.

[8] Martin R. J., Deo B. Effect of plant population on calendula (Calendula officinalis L.) Flower production. Journal of Crop and Horticultural Science. 2000, 28: 37-44.

[9] Cromack H. T. H., Smith J. M. Calendula officinalis Production Potential and Crop Agronomy in Southern England. Industrial Crops and Products. 1998, 7: 223-229.

[10] Kalvatchev Z., Walder R., Garzaro D. Anti-HIV activity of extracts from Calendula officinalis flovers. Biomedicine \& Pharmacotherapy. 1997, 51 (4): 76-180. 
[11] Tessier A., Campbell P. G. C., Bisson M. Sequential extraction procedure for the speciation of particulate trace metals. Analytical Chemistry. 1979, 51: 844-851.

[12] Yoon J. X., Cao Q., Zhou L. Q. Accumulation of $\mathrm{Pb}, \mathrm{Cu}$, and $\mathrm{Zn}$ in native plants growing on a contaminated Florida site. Science of the Total Environment, 2006, 368: 456-464.

[13] Wong M. H. Ecological restoration of mine degraded soils, with emphasis on metal contaminated soils. Chemosphere, 2003, 50: 775-780.

[14] Elliot H. A., Liberati M. R., Huang C. P. Competitive adsorption of heavy metals by soils. J Environ Qual. 1986, 15: 214-219.

[15] Harter R. D., Naidu R. An Assessment of Environmental and Solution Parameter Impact on Trace Metal Sorption by Soils. Soil Science Society of American Journal. 2001, 65: 597-612.

[16] McBride M. B., Environmental Chemistry of soils. Oxford University Press, New York. 1994.

[17] Milivojević J., Đalović I., Jelić M., Trifunović S., Bogdanović D., Milošev D., Nedeljković B., Bjelić D. Distribution and forms of manganese in vertisols of Serbia. Journal of the Serbian Chemical Society. 2011, 76 (8) 1177-1190.
[18] Sahito S. R., Memon M. A., Kazi T. G., Kazi G. H. Evaluation of mineral contents in medicinal plant Azadirachta indica. $J$ Chem Soc Pakistan. 2003, 25: 139-143.

[19] Jabeen S., Tahir Shah M., Khan S., Qasim Hayat M. Determination of major and trace elements in ten important folk therapeutic plants of Haripur basin, Pakistan. J Med Plants Res. 2010, 4 (7): 559-566.

[20] Ubavić M., Bogdanović D. Agrohemija. Institut za vrtlarstvo i povrtlarstvo, Novi Sad. 2001.

[21] Dučić T., Polle A. Transport and detoxification of manganese and cooper in plants. Brazilian Journal of Plant Physiology. 2005, 17 (1): 103-112.

[22] Abou-Arab A. A. K., El Tantawy M. S., Badeaaa R. I., Khayria N. Food Chemistry. 1999, 67: 357.

[23] Hayashi I. F., Herawati N., Rivai I. F., Koyama H., Suzuki S., Cadmium, Copper and Zinc Levels in Rice and Soil of Japan, Indonesia and China by Soil Type. Bull. Environmental Contamination and Toxicology. 2000, 64: 33-39.

[24] Li M. S., Luo Y. P., and Su Z. Y. Heavy metal concentrations in soils and plant accumulation in a restored manganese mineland in Guangxi, South China. Environmental Pollution. 2007, 149: 168-175. 